\title{
Optimization of a technique to quantify the total phenolic compounds in jambolan (Syzygium cumini Lamark) pulp
}

\author{
Otimização da técnica de quantificação de compostos \\ fenólicos totais na polpa de jambolão \\ (Syzygium cumini Lamark)
}

\author{
Taís Silva de Oliveira Brandão ${ }^{*}$ (1) , Lorena Silva Pinho1, Elisa Teshima ${ }^{1}$, \\ Jorge Mauricio David ${ }^{2}$, Maria Isabel Rodrigues ${ }^{3}$
}

\begin{abstract}
${ }^{1}$ Universidade Estadual de Feira de Santana (UEFS), Departamento de Tecnologia, Feira de Santana/BA - Brasil ${ }^{2}$ Universidade Federal da Bahia (UFBA), Instituto de Química, Salvador/BA - Brasil

${ }^{3}$ Protimiza - Consultoria e Treinamento em Planejamento de Experimentos e Otimização de Processos,

Campinas/SP - Brasil
\end{abstract}

*Corresponding Author: Taís Silva de Oliveira Brandão, Universidade Estadual de Feira de Santana (UEFS), Departamento de Tecnologia, Curso Engenharia de Alimentos, Avenida Trans-Nordestina, Caixa Postal: 252/294, CEP: 44036-900, Feira de Santana/BA - Brasil, e-mail: tbrandao@uefs.br

Cite as: Brandão, T. S. O., Pinho, L. S., Teshima, E., David, J. M., \& Rodrigues, M. I. (2019). Optimization of a technique to quantify the total phenolic compounds in jambolan (Syzygium cumini Lamark) pulp. Brazilian Journal of Food Technology, 22, e2018158. https://doi.org/10.1590/1981-6723.15818

\begin{abstract}
There are various known extraction methods that can be applied to the quantification of phenolic compounds, and thus it is up to the researcher to perfect the process that best applies to the sample in question. Different extraction solvents (liquid-liquid extraction) were compared in order to assess their effectiveness for the analysis of total phenols in jambolan (Syzygium cumini Lamark) pulp extract using the conventional Folin-Ciocalteau methodology. Three CCRDs (Central Composite Rotational Designs) were carried out to evaluate the factors influencing the extraction process conditions. The variables studied were the solvent concentration (ethanol and methanol, diluted in water) and the mixing time in the compound extraction process. Of the conditions studied, it was shown that a $60 \%$ ethanol in water extraction solvent with a mixing time of 10 minutes, in addition to extracting a greater concentration of phenolic compounds, showed the greatest cost benefit advantage, since ethanol is cheaper and less toxic than methanol.
\end{abstract}

Keywords: Syzygium cumini Lamark; Extraction solution; Polyphenols; Validation; Folin-Ciocalteau; Spectrophotometry.

\section{Resumo}

São conhecidos vários métodos de extração que podem ser aplicados para a quantificação de compostos fenólicos e, portanto, cabe ao pesquisador aperfeiçoar o processo que melhor se aplica à amostra em questão. Diferentes solventes de extração (extração líquido-líquido) foram comparados a fim de avaliar a sua eficácia para a análise de fenóis totais em extrato de polpa de jambolão (Syzygium cumini Lamark), usando metodologia convencional de 
Folin-Ciocalteau. Três DCCRs (Delineamento composto central rotacional) foram realizados para avaliar os fatores que influenciam as condições de processo de extração. As variáveis estudadas foram a concentração de solvente (etanol e metanol, diluído em água) e o tempo de mistura no processo de extração de compostos. Das condições estudadas, foi demonstrado que um solvente de extração $60 \%$ de etanol em água, com um tempo de mistura de 10 minutos, além de extrair uma maior concentração de compostos fenólicos, apresenta grande vantagem de custobenefício, uma vez que o etanol é mais barato e menos tóxico do que o metanol.

Palavras-chave: Syzygium cumini Lamark; Solução extratora; Polifenóis; Validação; Folin-Ciocalteau; Espectrofotometria.

\section{Introduction}

The phenolic compounds are secondary metabolites of vegetable products, forming an extensive complex group as responses to ecological and physiological pressures (Vermerris \& Nicholson, 2006; Silva et al., 2018). They are commonly found in plant sources and can be defined as substances that have at least one hydroxylated benzene ring. The phenolic compounds have been reported as having a variety of biological effects, including antioxidant activity, which has created a great impact on human activities in the agroindustrial and food sectors (Inglett \& Chen, 2011; Kamboj et al., 2015).

Syzygium cumini (L.) Skeels (Sin. Eugenia jambolana Lamark, Myrtaceae) is a tropical perennial leafy tree that originated in India and Sri Lanka. The fruits are ovoid, fleshy, dark purple and single seeded and have a sweet, astringent flavor, ripening between the months of January and March. They grow spontaneously in hot climates and are well known in Brazil, where they are popularly known as "jamelão", "jambolão" or "black olive" because of their ovoid fruits (Sehwag \& Das, 2014; Lima et al., 2007; Lorenzi et al., 2006).

There are indications that the extractive yield of bioactive compounds, and even their pharmacological properties, in the present case, the ability to deactivate free radicals, are influenced by the method and solvent used (Veber et al., 2015). There are a variety of studies that have shown the importance of sample preparation in chemical analyses, and attention to this question is growing in the determination of phenolic compounds in vegetable products, particularly in fruits. Sample preparation is a critical step in the analysis, since errors can be incorporated into the final results. This is even more significant in real samples in which the component matrix is biologically active, and the analytes represent a vast spectrum of compounds, many of unknown identity (Luthria, 2006; Antolovich et al., 2000; Bailão et al., 2015). Knowledge of the factors that influence processing conditions is required to improve the extraction efficiency of any bioactive compound (Pompeu et al., 2009).

With respect to the extraction of phenolics from fruits, there is no single way of selecting the most efficient methodology, since it can suffer the influence of various factors. Of these one can cite the physiological state of the fruit when harvested, the storage conditions, the solvent used in extraction, the surface contact area, their interaction with other components in the matrix, the extraction technique, and the extraction time and temperature (Luthria, 2006; Shahidi \& Naczk, 1995; Kamboj et al., 2015). Thus, various extraction methods exist which can be applied in the quantification of phenolic compounds, it being necessary to perfect the process that best suits the sample of interest.

It is known that the quantitative determination of polyphenols is hampered by their structural complexity and diversity, however, several methods have been used to determine polyphenols in plant extracts (Blainski et al., 2013). Chromatographic methodology is considered to be the most important analytical tool in the quantitative determination of phenolic compounds, the traditional colorimetric methodology frequently being employed for this purpose since it is quick to use, applicable in routine laboratory use, and of low cost (Blainski et al., 2013; Cicco \& Lattanzio, 2011; Pizarro et al., 2013). 
The traditional methodology for the determination of phenolic compounds dates from 1912 and was improved by Professor Vernon Singleton during the 1960s and 1970s. The basic mechanism is an oxidation/ reduction reaction, with the phenolic group being oxidized and the metal ion reduced (Agbor et al., 2014; Kamboj et al., 2015).

The objective of this study was to standardize the extraction methodology for the quantification of phenolic compounds in jambolan using a central compound rotational design (CCRD).

\section{Material and methods}

Mature jambolan fruits were picked on the State University of Feira de Santana (UEFS) campus, Brazil, and selected according to their state of conservation. The whole pulp was extracted using an industrial fruit pulper (Itametal).

The strategy for the optimization of the total phenolic compound determination was based on studies that indicated that the preparation of a sample for the extraction of phenolic compounds is influenced not only by the constituent phenolics, but also by the type of solvent used. Different solvents result in significant variability in the phenolic concentration, apart from the influence of the concentration of the extracting solution (Luthria, 2006).

A $2^{2}$ central composite rotational design (CCRD) with 3 central and 4 axial points, was chosen to investigate the effects of mixing time and solvent concentration in the optimization process for the extraction of phenolic compounds from jambolan pulp. The axial points were used to determine the degrees of freedom and evaluation of the quadratic equation, and the central points to evaluate the intermediate conditions to the extremes studied, in addition to the repeatability of the process. The statistical project was carried out according to Rodrigues \& Iemma (2012).

The solvents were ethanol/water, methanol/water and ethanol/methanol/water. Three CCRDs were carried out, one for each solvent, each with 11 trials and with the addition of 6 control trials for each CCRD $(100 \%$ water and $100 \%$ solvent), and the experiments were carried out in a random order. The choices of the variables and the ranges of values studied were chosen according to preliminary tests and a literature review.

Table 1 shows the real and coded experimental values used. It can be seen that according to the solvent (ethanol or methanol, dissolved in water) ratio used, the solvent concentration varied from $8 \%$ to $80 \%$, and the mixing time varied from 10 to 30 minutes.

Table 1. Real and coded levels for the variables of the CCRDs for the extraction with alcoholic solutions of ethanol, methanol and the ratio between ethanol, methanol and water.

\begin{tabular}{lcccccc}
\hline & Variable & $\mathbf{- 1 . 4 1}$ & $\mathbf{- 1}$ & $\mathbf{0}$ & $\mathbf{1}$ & $\mathbf{1 . 4 1}$ \\
\hline CCRD 1 & Ethanol (\%) & 0.4 & 0.46 & 0.6 & 0.74 & 0.8 \\
CCRD 2 & Methanol (\%) & 0.4 & 0.46 & 0.6 & 0.74 & 0.8 \\
CCRD 3 & Ratio Ethanol/Methanol (\%) & $0.08 / 0.32$ & $0.14 / 0.32$ & $0.3 / 0.3$ & $0.52 / 0.22$ & $0.64 / 0.16$ \\
& Mixing time (min)* & 10 & 13 & 20 & 27 & 30 \\
\hline
\end{tabular}

*The mixing time varied from 10 to 30 minutes in the three designs.

In order to obtain the maximum amount of information and the best conditions to define the solvent concentration, the data set was analyzed using the concentration of phenolic compounds expressed in $\mathrm{mg} / 100 \mathrm{~g}$ pulp. The statistical analysis was carried out using the STATISTICA 7.0 software (Statsoft Inc., Tulsa, OK, USA).

The extracts were prepared from the frozen pulp using the solvent concentrations determined in the experimental designs as the parameter, the concentrations varying between $8 \%$ and $80 \%$. To prepare the extracts, conical flasks containing the extraction solution and the pulp were submitted to constant shaking in a shaken incubation chamber at room temperature $\left(28^{\circ} \mathrm{C}\right)$, the extraction time varying between 10 and 30 minutes. After mixing, the mixtures were filtered under vacuum to obtain the extracts. 
The concentration of total phenolic compounds was determined according to the conventional spectrophotometric procedure developed by Folin-Ciocalteau (Singleton \& Rossi, 1965) and adapted by Georgé et al. (2005). Gallic acid was used as the reference to prepare the standard curve and the results were expressed in mg gallic acid per $100 \mathrm{~g}$ of pulp. All the extracts and the gallic acid were dissolved in distilled water. The reaction medium, which consisted of $500 \mu \mathrm{L}$ of the ethanolic extract plus $2.5 \mathrm{~mL}$ Folin-Ciocalteau solution $(1: 10)$ and $2.0 \mathrm{~mL}$ of a $7.5 \%$ sodium carbonate solution, was prepared in $10 \mathrm{~mL}$ test tubes. The tubes were shaken, placed in a water bath at $50{ }^{\circ} \mathrm{C}$ for 15 minutes, and the absorbance then measured at $760 \mathrm{~nm}$. As described by Verza et al. (2007), the blanks were obtained by substituting the sample volume with distilled water, maintaining the same amounts of Folin-Ciocalteau reagent and sodium carbonate solution.

\section{Results and discussion}

Table 2 shows the results obtained for the concentrations of phenolic compounds in the three CCRDs using the different extraction solutions.

Table 2. Coded values $\left(\mathrm{x}_{1}\right.$ and $\left.\mathrm{x}_{2}\right)$ for the variables studied in the designs and the responses for phenolic compounds corresponding to the extraction solutions of ethanol $\left(\mathrm{Y}_{1}\right)$, methanol $\left(\mathrm{Y}_{2}\right)$ and the ethanol/methanol mixture $\left(\mathrm{Y}_{3}\right)$.

\begin{tabular}{|c|c|c|c|c|c|}
\hline \multirow{2}{*}{ Trials } & \multicolumn{2}{|c|}{ Variables } & \multicolumn{3}{|c|}{ Responses (mg/100 g) } \\
\hline & $\mathbf{x}_{1} *$ & $\mathrm{x}_{2} * *$ & $Y_{1}$ & $Y_{2}$ & $\mathbf{Y}_{3}$ \\
\hline 1 & -1 & -1 & $331.2( \pm 4.15)$ & $293.5( \pm 1.82)$ & $286.9( \pm 3.06)$ \\
\hline 2 & 1 & -1 & $348.7( \pm 3.11)$ & $301.8( \pm 3.91)$ & $304.2( \pm 4.12)$ \\
\hline 3 & -1 & 1 & $386.4( \pm 2.49)$ & $303.2( \pm 3.37)$ & $276.3( \pm 2.97)$ \\
\hline 4 & 1 & 1 & $348,0( \pm 2.13)$ & $319,0( \pm 4.17)$ & $220.6( \pm 2.83)$ \\
\hline 5 & -1.41 & 0 & $434.8( \pm 3.19)$ & $350.7( \pm 4.05)$ & $281.0( \pm 1.05)$ \\
\hline 6 & 1.41 & 0 & $391.4( \pm 4.73)$ & $332.7( \pm 2.24)$ & $270.3( \pm 1.85)$ \\
\hline 7 & 0 & -1.41 & $320.7( \pm 2.92)$ & $304.6( \pm 4.31)$ & $283.7( \pm 3.14)$ \\
\hline 8 & 0 & 1.41 & $312,0( \pm 2.46)$ & $310.0( \pm 3.61)$ & $269.7( \pm 3.35)$ \\
\hline 9 & 0 & 0 & $375.3( \pm 3.06)$ & $339.1( \pm 3.71)$ & $302.8( \pm 4.09)$ \\
\hline 10 & 0 & 0 & $368.4( \pm 2.83)$ & $326.0( \pm 1.48)$ & $278.7( \pm 3.85)$ \\
\hline 11 & 0 & 0 & $372.2( \pm 3.17)$ & $330.6( \pm 4.81)$ & $301.4( \pm 2.72)$ \\
\hline \multirow{6}{*}{ Controls } & \multirow{3}{*}{0} & \multirow{3}{*}{$100 \%$ water } & 214.6 & 193.6 & 146.9 \\
\hline & & & 185.8 & 189.2 & 140.7 \\
\hline & & & 189.0 & 186.3 & 126.8 \\
\hline & \multirow{3}{*}{0} & \multirow{3}{*}{$100 \%$ solvent } & 285.0 & 276.9 & 236.2 \\
\hline & & & 277.3 & 257.7 & 232.3 \\
\hline & & & 306.5 & 289.3 & 249.3 \\
\hline
\end{tabular}

${ }^{*} \mathrm{x}_{1}=$ coded variable for mixing time. ${ }^{*} \mathrm{x}_{2}=$ coded variable for $\%$ solvent.

It can be seen that the best results for phenolic compounds were obtained with the solvent ethanol (Y1), varying from 312 to $434.8 \mathrm{mg} / 100 \mathrm{~g}$ fruit pulp. The values were between 293.5 and $350.7 \mathrm{mg} / 100 \mathrm{~g}$ for the solvent methanol (Y2), and between 220.6 and $304.2 \mathrm{mg} / 100 \mathrm{~g}$ pulp for the mixture of the two solvents (Y3). The values obtained using $100 \%$ aqueous extraction or $100 \%$ solvent extraction were much smaller than those obtained using solvent/water solutions.

The jambolan pulp treated with $60 \%$ ethanol as the solvent and a mixing time of 10 minutes (Test 5) showed a higher phenolic compound content $(434.8 \mathrm{mg} / 100 \mathrm{~g})$ than those found by other authors. Under these conditions, in addition to presenting a greater concentration of phenolic compounds, it showed the greatest cost benefit advantage, since in addition to being cheaper, ethanol is less toxic than methanol. In a study carried out by Kuskoski et al. (2006), using the same methodology and solvent, the ethanolic jambolan extract showed a value of $229.6 \pm 13.6 \mathrm{mg} / 100 \mathrm{~g}$, Luximon-Ramma et al. (2003), found $235.9 \mathrm{mg} / 100 \mathrm{~g}$ in a acetone/methanol/water extract, and Faria et al. (2011), found $148.3 \mathrm{mg} / 100 \mathrm{~g}$ in a methanol/water extract. However, a higher concentration $(930.4 \mathrm{mg} / 100 \mathrm{~g})$ was obtained by Vizzotto \& Pereira (2008) using the 
solvent methanol and expressing the result in $\mathrm{mg}$ of chlorogenic acid equivalents $/ 100 \mathrm{~g}$ fresh sample. According to Veber et al. (2015), 50\% ethanol/water extracts provide the largest total phenolic compound contents, independent of the plant material studied. This suggests that apart from the solvent used in the extraction, variations in the climate and in the state of maturation of the fruit can also influence the biosynthesis of these compounds (Vizzotto \& Pereira, 2008).

Table 3 shows the values obtained for the regression coefficients and the corresponding p-values. The level of significance established $\grave{a}$ priori in the statistical analysis was $10 \%$, since the raw material was obtained from a fruit, different from processes where there is greater standardization and control of the system under study.

Table 3. Regression coefficients and p-values for the CCRDs (Y1 is ethanol/water, Y2 is methanol/water and Y3 is the ethanol/methanol/water mixture).

\begin{tabular}{|c|c|c|c|c|c|c|}
\hline \multirow[b]{2}{*}{ Factors } & \multicolumn{2}{|c|}{ Y1 } & \multicolumn{2}{|c|}{ Y2 } & \multicolumn{2}{|c|}{ Y3 } \\
\hline & $\begin{array}{c}\text { Regression } \\
\text { coefficient*** }\end{array}$ & $p$-value & $\begin{array}{c}\text { Regression } \\
\text { coefficient } * * *\end{array}$ & $p$-value & $\begin{array}{c}\text { Regression } \\
\text { coefficient** }\end{array}$ & $p$-value \\
\hline Mean & 372.01 & $<0.0001$ & 332.00 & $<0.0001$ & 294.20 & $<0.0001$ \\
\hline $\mathrm{X} 1\left(\mathrm{~L}^{*}\right)$ & -10.30 & 0.0986 & -0.17 & 0.9773 & -4.92 & 0.3849 \\
\hline $\mathrm{X} 1\left(\mathrm{Q}^{*}\right)$ & 17.88 & 0.0320 & -0.18 & 0.9801 & -5.95 & 0.3795 \\
\hline $\mathrm{X} 2\left(\mathrm{~L}^{*}\right)$ & 5.27 & 0.3473 & 4.33 & 0.4732 & 1.51 & 0.7826 \\
\hline $\mathrm{X} 2\left(\mathrm{Q}^{*}\right)$ & -30.78 & 0.0038 & -17.49 & 0.0469 & -5.43 & 0.4191 \\
\hline $\mathrm{X} 1 . \mathrm{X} 2$ & -13.99 & 0.1088 & 1.85 & 0.8234 & -0.76 & 0.9217 \\
\hline
\end{tabular}

*(L) linear and (Q) squared terms of the model. **Regression coefficients statistically significant at $90 \%$ of confidence $(p<0.10)$ in bold.

The ANOVAs were carried out (Table 4) for the different solvents studied, considering only the terms statistically significant at $p<0.10$. It can be seen at the Equation 1, that a re-parameterized codified model expressing the concentration of phenolic compounds as a function of the variables studied could only be obtained for the response Y1 (CCRD using an extraction solvent of ethanol):

$\mathrm{Y} 1=372.01-10.3 \mathrm{x}_{1}+17.9 \mathrm{x}_{1}^{2}-30.8 \mathrm{x}_{2}^{2}-14.0 \mathrm{x}_{1} \mathrm{x}_{2}$

As can be seen from the table of results, this occurred because only the design using ethanol as the solvent showed a significant variation in the responses as a function of the conditions studied in the CCRDs, allowing one to obtain the response surface and contour curves for this response as shown in Figures 1A and 1B.

Table 4. Values for the percent variation explained $\left(\mathrm{R}^{2}\right)$ and the values for $\mathrm{F}_{\text {cal }}$ and $\mathrm{F}_{\text {tab }}$ for the CCRDs carried out.

\begin{tabular}{cccc}
\hline Solvents & $\mathbf{R}^{\mathbf{2}} \mathbf{( \% )}$ & $\mathbf{F}_{\text {cal }}$ & $\mathbf{F}_{\text {tab }}$ \\
\hline Y1 (Ethanol) & 90.00 & 13.6 & 3.18 \\
Y2 (Methanol) & 56.92 & 11.89 & 3.36 \\
Y3 (Ethanol/methanol mixture) & 31.72 & 0.46 & 3.45 \\
\hline
\end{tabular}




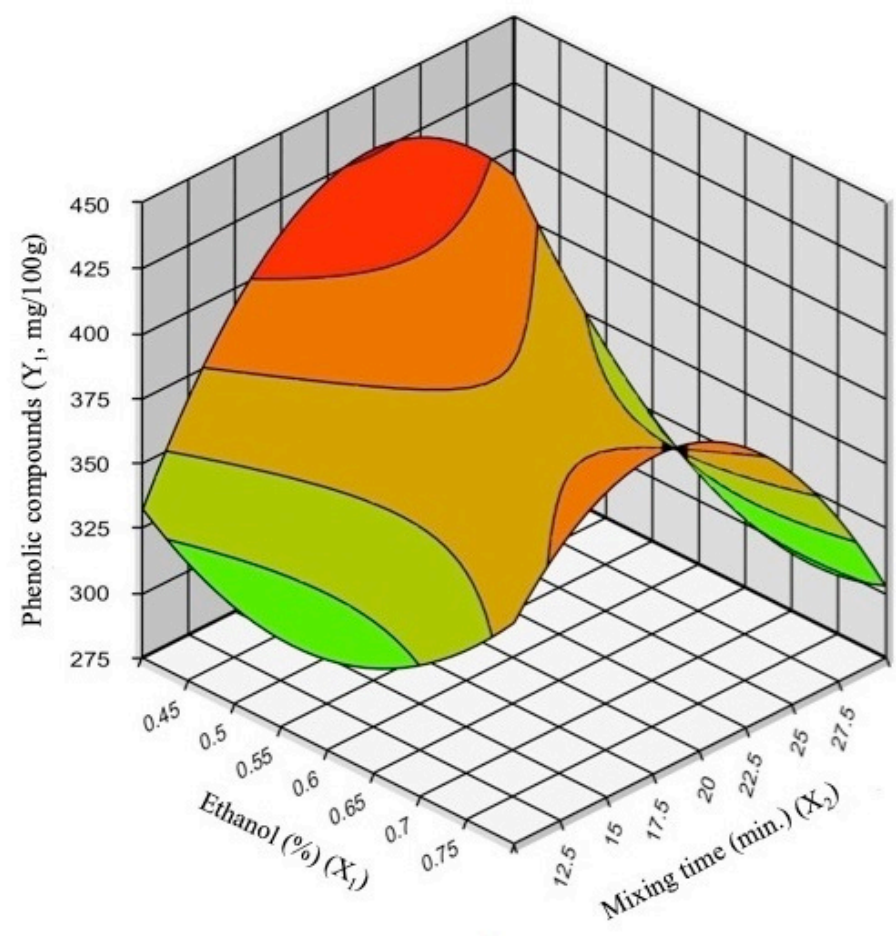

A

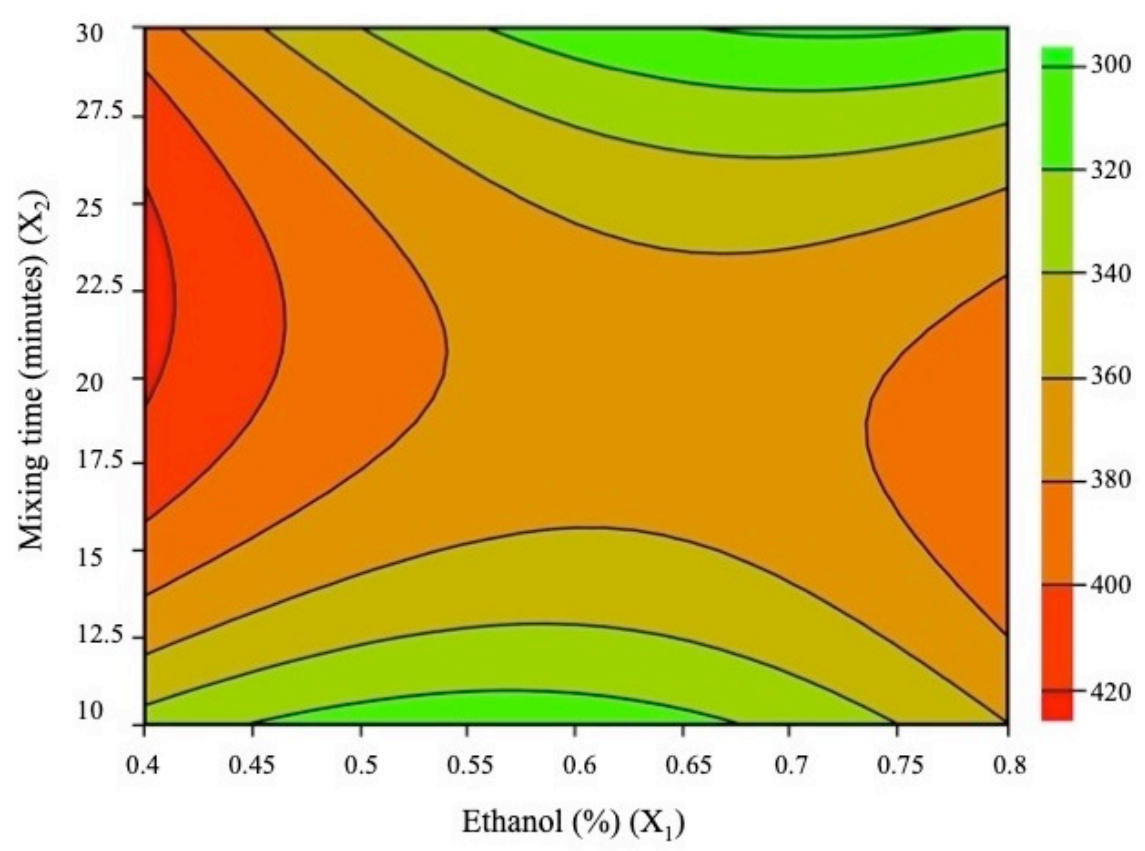

B

Figure 1. Response surface (A) and contour curves (B) as a function of mixing time and solvent concentration for the solvent ethanol.

Thus, as observed by Borges et al. (2011), within the range studied of from 10 to 30 minutes, the mixing time affected the response. It was shown in the present experiment that an increase in extraction time reduced the concentration of phenolic compounds. The ethanol concentration can be established at about $60 \%$, the central condition of the design (Figure 2). 


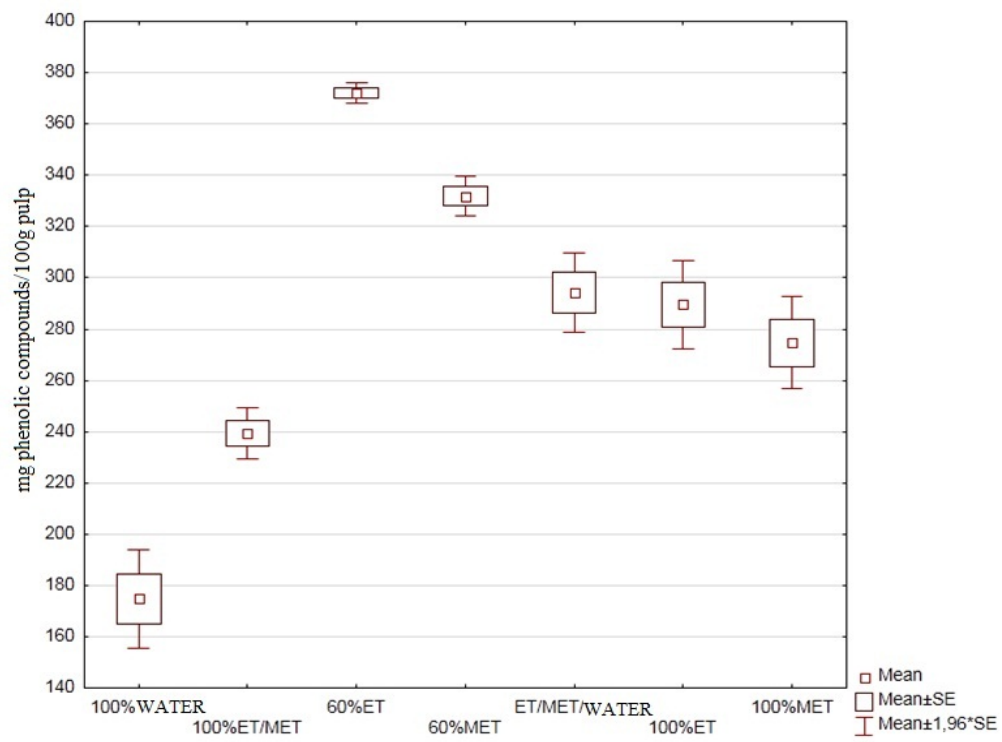

Figure 2. Tukey's analysis for the different solvent concentrations and conditions studied.

This same solvent concentration $(60 \%)$ was used by Kuskoski et al. (2006), to obtain ethanolic and methanolic jambelon extracts. As observed in the present study, higher concentrations of phenolic compounds were obtained in the ethanolic extracts (Kuskoski et al., 2006) when compared to the methanolic extracts.

As from the optimized results, the extraction conditions and quantification of the total phenolic compounds was validated. The analyses were carried out in triplicate with a solvent of ethanol at concentrations of $50 \%$ and $60 \%$ and mixing times of 5 and 10 minutes. The means difference test was applied to evaluate the difference between the conditions studied.

The Tukey's test (Figure 3) carried out on the validation trials showed that the extraction with $50 \%$ ethanol for 5 minutes was statistically different from the other conditions, giving a lower concentration of phenolic compounds $/ 100 \mathrm{~g}$ pulp. The extraction conditions of $50 \%$ ethanol for 10 minutes and of $60 \%$ ethanol for 5 minutes were not statistically different. The treatment carried out with $60 \%$ ethanol for 10 minutes extracted the greatest amount, namely $394.9 \pm 13.04 \mathrm{mg}$ of phenolic compounds/ $100 \mathrm{~g}$ pulp.
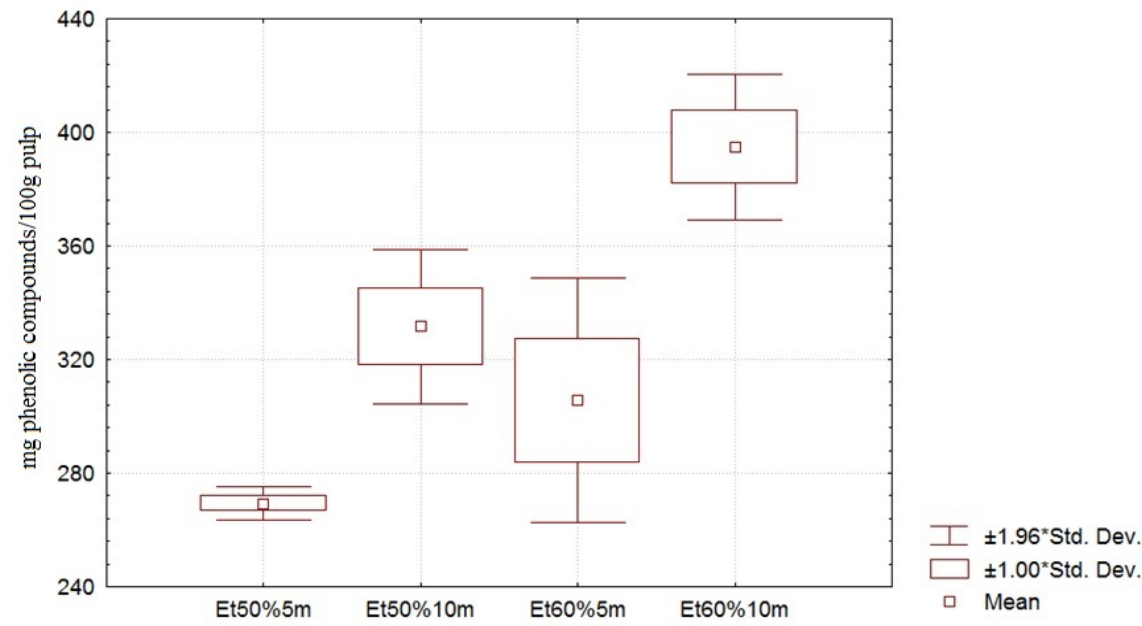

Figure 3. Tukey's analysis in the validation of the optimized conditions. 
Although the Folin-Ciocalteau method is the one most used to quantify phenolic compounds, the FolinCiocalteau reagent can interact with other, non-phenolic chemical compounds such as carotenoids, amino acids, sugars and vitamin $\mathrm{C}$, which can lead to an overestimation of the total phenolic compounds (LuximonRamma et al., 2003; Georgé et al., 2005). Thus some authors have suggested an additional step in the analysis of the total phenolics, that is, the quantification of ascorbic acid or its destruction by heat or acid conditions, as carried out by Vinson et al. (2001), considering that the ascorbate reacts with the Folin (oxidation-reduction reaction). According to Luximon-Ramma et al. (2003), faced with all the limitations, it might be more adequate to use the term Folin-Ciocalteau index instead of total phenolic compounds. However, this point was not considered in the present study.

Thus, this study presented a protocol for the extraction and determination of the total phenolic composition of jambolan pulp, with an effective reduction in the number of experiments and improved quality in the analysis of the results. The use of this statistical tool was highly useful in the development of the analytical procedures and could be used for other fruit pulps.

\section{Conclusion}

The use of an experimental design indicated the most adequate conditions to obtain the best results for the total phenolic concentrations. It was shown that, under the conditions of the experiment, it was possible to find the ideal conditions for the system: $60 \%$ ethanolic extraction solution in an aqueous medium as the best concentration and solvent, used with a mixing time of 10 minutes, resulting in the determination of a phenolic compound concentration to the order of $414,9 \mathrm{mg} / 100 \mathrm{~g}$ jambolan pulp, considering the mean of the concentrations of the triplicates used in the validation and the triplicates of the CCRD.

\section{Acknowledgements}

The authors are grateful to FAPESB - Fundação de Amparo à Pesquisa do Estado da Bahia for the Masters' scholarship awarded.

\section{References}

Agbor, G. A., Vinson, J. A., \& Donnelly, P. E. (2014). Folin-ciocalteau reagent for polyphenolic assay. International Journal of Food Science, Nutrition and Dietetics, 3(8), 147-156. http://dx.doi.org/10.19070/2326-3350-1400028.

Antolovich, M., Prenzler, P., Robards, K., \& Ryan, D. (2000). Sample preparation in the determination of phenolic compounds in fruits. Analyst, 125(5), 989-1009. http://dx.doi.org/10.1039/b000080i

Bailão, E. F. L. C., Devilla, I. A., da Conceição, E. C., \& Borges, L. L. (2015). Bioactive compounds found in Brazilian Cerrado fruits. International Journal of Molecular Sciences, 16(10), 23760-23783. PMid:26473827. http://dx.doi.org/10.3390/ijms161023760

Blainski, A., Lopes, G. C., \& Mello, J. C. (2013). Application and analysis of the folin ciocalteu method for the determination of the total phenolic content from Limonium brasiliense L. Molecules, 18(6), 6852-6865. PMid:23752469. http://dx.doi.org/10.3390/molecules18066852

Borges, G. S. C., Vieira, F. G. K., Copetti, C., Gonzaga, L. V., \& Fett, R. (2011). Optimization of the extraction of flavanols and anthocyanins from the fruit pulp of Euterpe edulis using the response surface methodology. Food Research International, 44(3), 708-715. http://dx.doi.org/10.1016/j.foodres.2010.12.025

Cicco, N., \& Lattanzio, V. (2011). The influence of initial carbonate concentration on the folin-ciocalteu micro-method for the determination of phenolics with low concentration in the presence of methanol: A comparative study of real-time monitored reactions. American Journal of Analytical Chemistry, 2(7), 840-848. http://dx.doi.org/10.4236/ajac.2011.27096

Faria, A. F., Marques, M. C., \& Mercadante, A. Z. (2011). Identification of bioactive compounds from jambolão (Syzygium cumini) and antioxidant capacity evaluation in different pH conditions. Food Chemistry, 126(4), 1571-1578. PMid:25213929. http://dx.doi.org/10.1016/j.foodchem.2010.12.007

Georgé, S., Brat, P., Alter, P., \& Amiot, M. J. (2005). Rapid determination of polyphenols and vitamin C in plant-derived products. Journal of Agricultural and Food Chemistry, 53(5), 1370-1373. PMid:15740008. http://dx.doi.org/10.1021/jf048396b

Inglett, G. E., \& Chen, D. (2011). Contents of phenolics and flavonoids and antioxidant activities in skin, pulp, and seeds of miracle fruit. Journal of Food Science, 76(3), 479-482. PMid:21535817. http://dx.doi.org/10.1111/j.1750-3841.2011.02106.x 
Kamboj, A., Gupta, R., Rana, A., \& Kaur, R. (2015). Application and analysis of the folin ciocalteu method for the determination of the total phenolic content from extracts of terminalia bellerica. European Journal of Biomedical and Pharmaceutical Sciences, 2, 201-2015.

Kuskoski, E. M., Asuero, A. G., Morales, M. T., \& Fett, R. (2006). Frutos tropicais silvestres e polpas de frutas congeladas: atividade antioxidante, polifenóis e antocianinas. Ciência Rural, 36(4), 1283-1287. http://dx.doi.org/10.1590/S010384782006000400037

Lima, L. A., Siani, A. C., Brito, F. A., Sampaio, A. L. F., Henriques, M. G. M. O., \& Riehl, C. A. S. (2007). Correlation of antiinflammatory activity with phenolic content in the leaves of Syzygium cumini (I.) skeels (myrtaceae). Química Nova, 30(4), 860864. http://dx.doi.org/10.1590/S0100-40422007000400019

Lorenzi, H., Bacher, L., Lacerda, M., \& Sartori, S. (2006). Brazilian fruit \& cultivated exotic. São Paulo: Instituto Plantarum de Estudos da Flora.

Luthria, D. L. (2006). Influence of sample preparation on the assay of phytochemicals. American Laboratory, 38(7), 12-13.

Luximon-Ramma, A., Bahorun, T., \& Crozier, A. (2003). Antioxidant actions and phenolic and vitamin C contents of common Mauritan exotic fruits. Journal of the Science of Food and Agriculture, 83(5), 496-502. http://dx.doi.org/10.1002/jsfa.1365

Pizarro, M. L., Becerra, M., Sayago, A., Beltrán, M., \& Beltrán, R. (2013). Comparison of different extraction methods to determine phenolic compounds in virgin olive oil. Food Analytical Methods, 6(6), 123-132. http://dx.doi.org/10.1007/s12161-0129420-8

Pompeu, D. R., Silva, E. M., \& Rogez, H. (2009). Optimisation of the solvent extraction of phenolic antioxidants from fruits of Euterpe oleracea using response surface methodology. Bioresource Technology, 100(23), 6076-6082. PMid:19581082. http://dx.doi.org/10.1016/j.biortech.2009.03.083

Rodrigues, M. I., \& lemma, A. F. (2012). Experimental design and process optimization. Campinas: Casa do Espírito Amigo Fraternidade Fé e Amor.

Sehwag, S., \& Das, M. (2014). Nutritive, therapeutic and processing aspects of Jamun, Syzygium cuminii (L.) skeels: An overview. Indian Journal of Natural Products and Resources, 5(4), 295-307.

Shahidi, F., \& Naczk, M. (1995). Food phenolics: Sources, chemistry, effects and applications (p. 235-273). Lancaster: Technomic Publishing.

Silva, M. O., Brigide, P., Toledo, N. M. V., \& Canniatti-Brazaca, S. G. (2018). Phenolic compounds and antioxidant activity of two bean cultivars (Phaseolus vulgaris L.) submitted to cooking. Brazilian Journal of Food Technology, 21, 1-8.

Singleton, V. L., \& Rossi, J. A. (1965). Colorimetry of total phenolics with phosphomolybdic-phosphotungstic acid reagents. American Journal of Enology and Viticulture, 16, 144-158.

Veber, J., Petrini, L. A., Andrade, L. B., \& Siviero, J. (2015). Determinação dos compostos fenólicos e da capacidade antioxidante de extratos aquosos e etanólicos de Jambolão (Syzygium cumini L.). Revista Brasileira de Plantas Medicinais, 17(2), 267-273. http://dx.doi.org/10.1590/1983-084X/12_181

Vermerris, W., \& Nicholson, R. (2006). Phenolic compound biochemistry. Dordrecht: Springer.

Verza, S. G., Kreinecker, M. T., Reis, V., Henriques, A. T., \& Ortega, G. G. (2007). Avaliação das variáveis analíticas do método de folin-ciocalteu para determinação do teor de taninos totais utilizando como modelo o extrato aquoso de folhas de Psidium guajava L. Química Nova, 30(4), 815-820. http://dx.doi.org/10.1590/S0100-40422007000400011

Vinson, J. A., Su, X., Zubik, L., \& Bose, P. (2001). Phenol antioxidant quantity and quality in foods: Fruits. Journal of Agricultural and Food Chemistry, 49(11), 5315-5321. PMid:11714322. http://dx.doi.org/10.1021/jf0009293

Vizzotto, M., \& Pereira, M. C. (2008). Caracterização das propriedades funcionais do jambolão (Boletim de Pesquisa e Desenvolvimento). Pelotas: Embrapa Clima Temperado. 